\title{
TOTAL SHIP OPERABILITY -REVIEW, CONCEPT AND CRITERIA
}

\author{
M. Hossein Ghaemi ${ }^{1}$ \\ Henryk Olszewski ${ }^{2}$ \\ ${ }^{1}$ Gdansk University of Technology, Poland \\ ${ }^{2}$ The State University of Applied Sciences in Elbląg, Poland
}

\begin{abstract}
The ship operability can be understood and analysed in different manners, and its quality is described using different indexes by different authors. Practically, there is no general and widely accepted description of total ship operability in the literature, nor in the rules of classification societies, which would include both seakeeping and manoeuvrability characteristics of a ship, and simultaneously take into account all ship subsystems and, what is most important, comfort and safety of people on board. The aim of this paper is to propose a general definition of total ship operability and name, adjust, describe and justify criteria which should be considered in the ship operability analysis, as well as to provide a relevant algorithm paving the road for further investigation on total ship operability determination.
\end{abstract}

Keywords: ship operability, operability limitation criteria, safe operation level

\section{INTRODUCTION}

At the beginning of the 21st century we observe intensive technology development in many areas, including ocean engineering (for example see Burdziakowski 2015, and Janowski 2014). It has been a usual practice now to perform complicated numerical analyses using different FEM or CFD techniques (for example see Sabik 2013). Advanced materials with high performance level are now used in practice. Safety plays a fundamental role in design and decision making processes. All of these advantages make it possible to solve the ship operability problem not only for a particular subsystem or ship hull, but also for the entire ship system. This refers to total ship operability.
The term "operability" is used in computer science, medicine, and engineering to describe the ability to keep a whole system, installation, equipment or a set of facilities in a safe and reliable functioning condition, according to pre-defined operational requirements. Therefore, in the case of a ship as a whole, with all subsystems and equipment, its operability should take into account four basic elements:

1. The ship type, purpose and structure (hull and ship body), its subsystems, equipment, installations, devices, extra modules, people on board, and cargo, as well as all interactions between them for a considered type of vessel, 2. Ship environment, external conditions, and shipenvironment interaction for a specific route, 
3. Requirements for safe and reliable functioning of all items named under point 1 which will respect all regulations, rules and owner demands,

4. A set of criteria which should be satisfied to respect all constraints specified under point 3.

Till now, there is no general and widely accepted description of total ship operability in the literature, nor in the rules of classification societies, which would include both seakeeping and manoeuvrability characteristics of the ship, and simultaneously take into account all ship subsystems and, what is most important, comfort and safety of people on board.

The aim of the paper is to deliver a general definition of total ship operability and name, adjust, describe and justify criteria which should be considered in the ship operability analysis, as well as to provide a relevant algorithm.

\section{STATE OF THE ART}

Various models and a wide range of criteria for analysing the ship operability can be found in the literature. However, there is no method which would simultaneously include all elements mentioned in Introduction and, what is more important, refer to the ship as a whole. There is no general and widely accepted description of total ship operability in the literature, nor in the rules of classification societies. An overview of the state of the art in this area is given below.

The conventional method to determine ship operability bases on a model of ship responses to a variety of sea states having the form of wave statistics tables (Naito et al., 2006). The fundamental operability method, which utilizes the scatter diagram, has been proposed by Nordenstrom (1973). This method is often referred to as the scatter analysis and determines thresholds in the wave scatter diagram.

To determine the thresholds, ship responses are to be calculated and then prepared in the form of most probable maximum value. This method has been proposed by Ochi (1981). The scatter analysis neglects chronology and duration of the accounting operations, and the influence of weather changes. To include these factors, Dallinga (2004) and Grin and Van De Voorde (2004) have proposed the scenario simulation technique.

De Wilde (2009) has proposed the persistency analysis method based on a large environment statistics dataset. This method takes into account the influence of changing weather. Feikens (2011) has proposed to adapt the persistency analysis to an offshore operation with multiple operational phases. This method makes it possible to determine the influence of weather variation on the assessed operations.

Vidal et al. (2015) have developed a parametric model to assess the operability of Offshore Support Vessels (OSV) via configuration-based design, considering the availability and capacity of the ship and its installations. The method generates a ranking of different designs with respect to the operability level and capital cost. The developed model consists of a series of parametric equations, solved via a configuration-based approach for specific modules including cranes, extra accommodation, and larger propulsion. The analysis takes into account different operating areas and different scenarios. In this study the operability is determined based on the percentage of time during which the ship and its installations are available for operation, so that $100 \%$ operability means the capability of 365 days of ship sailing with faultless operation of its equipment, subsystems and installations, see Fig. 1 . That study rationally addresses the following options: extra accommodation, extra bollard pull, extra power, extra crane, dynamic positioning (DP1, DP2 or DP3), ice class; x-bow; extra moon pool, extra ROV, and helipad, which should be additionally considered for an OSV and are directly related to the operability of the vessel.

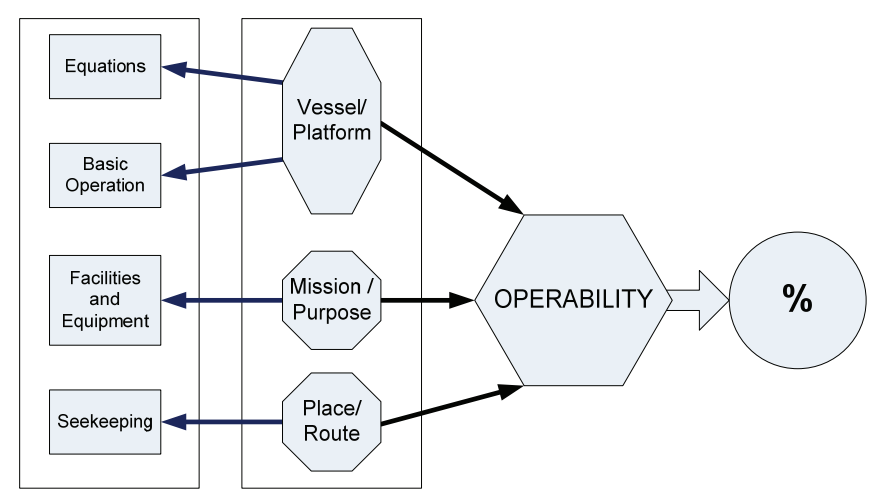

Figure 1. Relations between the ship and its operability, mission and route or place (Vidal, 2015).

Rusu and Bernardino (2009) have applied an assessment method to determine the operability index of a container ship in the Black Sea. In that study the operability is considered as the percentage of time during which the considered vessel is operational, depending on: (1) wave characteristics of the sailing area, (2) dynamic ship response to the waves, and (3) the ship mission. The relation between the ship operability and its mission was determined based on the seakeeping criteria. The operability index is understood in that study as degradation of ship ability to carry out its mission in calm water conditions.

Beside wave characteristics, Mudronja et al. (2014) have added some ship manoeuvrability characteristics to the operability analysis and presented the numerical results for a 9200 TEU container ship in extreme seas. They showed the influence of manoeuvring on wave loads, which then affects the ship operability. They suggested improving the approach to manoeuvring calculations by connecting them to the ship operability and wave load calculations in future studies. The operability was defined by them as the sustainable level of course and speed of navigation for each sea state shown by polar plots, or appropriate manoeuvres for bow heading navigation in different sea states illustrated by the so-called operability diagram, which splits the manoeuvring conditions into 4 groups of commands: no change, speed reduction, route change, and no solution. 

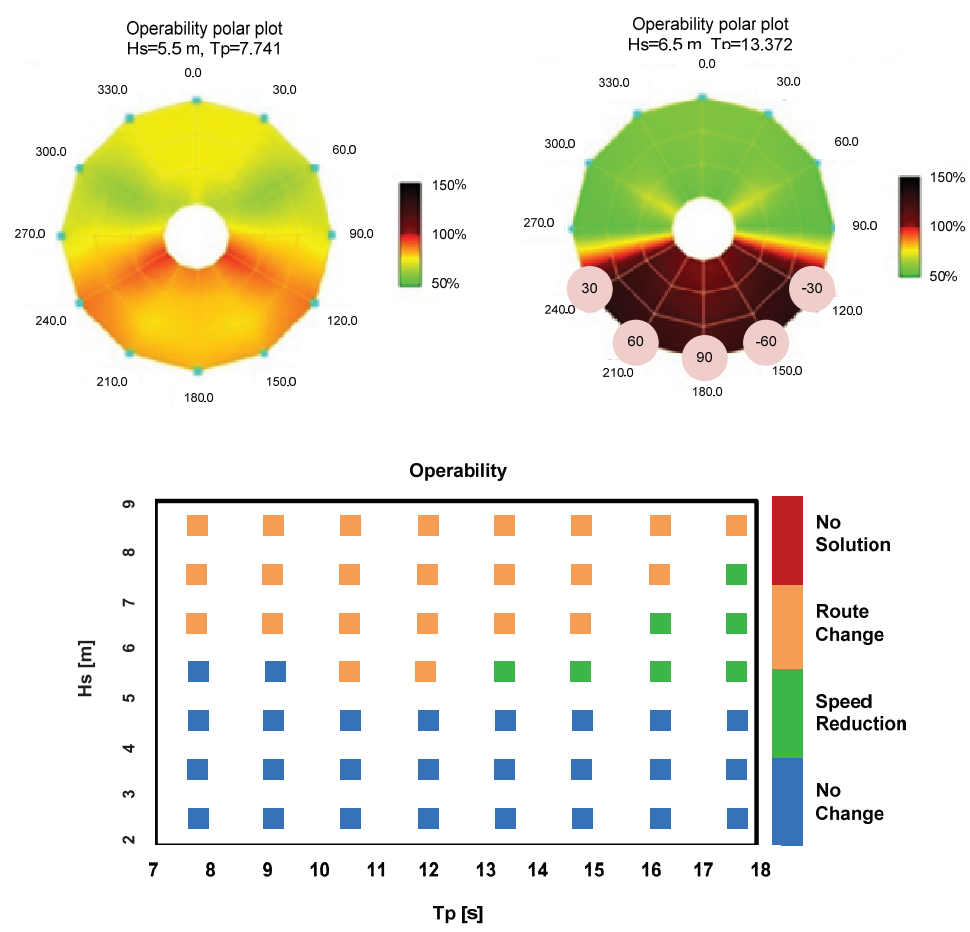

Figure 2. Sample percentages of limiting values for two different sea states (top) and the operability diagram (bottom), Mudronja et al. (2014).

The sample operability diagram is shown in Fig. 2.

The results of the study by Pipchenko and Zhukov (2011), which concerned ship control optimization in heavy weather conditions, show how the criteria for general ship operability limits influence the ship control strategy. The study takes into account risk and seaworthiness assessments and then applies the fuzzy logic multi-criteria assessment system to evaluate the decision by calculating the seakeeping efficiency. It is noteworthy that the problem of ship control should be understood as total ship control, taking into account collision avoidance manoeuvres and collision risk (Szłapczyński 2015).

Tezdogan et al. (2014) have assessed the operability of high speed passenger ships based on human comfort criteria. Understanding the operability in a similar way, Samson and Parsons (2002) have proposed its definition based on general motion limits related to biomechanical and physiological effects, which, when exceeded, lead to the degradation of human comfort.

Hutchison (1981) has proposed to analyse the ship operability in two manners: first as a multiple-criteria problem leading to the generation of the operability diagram in which the operability domain is described in terms of significant wave height and mean period (Hs and Tp in Fig. 3 , respectively). Here, the operability is determined based on the so-called "downtime" during which the ship is out of operation, with the seakeeping characteristics being the main decision criteria. The second manner concerns projects in which one critical activity occurs repeatedly in time, and the results include the so-called "delayed time" of each ship system function resulting from the inoperability of that system or the ship as a whole.
Zeraatgar et al (2012) have presented a study in which a naval ship was considered as a complete system. They proposed a method to establish which subsystem of the ship fails to perform its function in harsh sea conditions. They showed how a ship designer can predict which subsystem is more sensitive to wave height and can become inoperable when encountering the sea waves.

The method applied by Mudronja et al (2015) concludes the above presented methods, delivering, as a result, operability guidelines for product tankers. It makes use of the seakeeping characteristics in relation to the following operability criteria: propeller emergence, deck wetness, and bow acceleration of a product tanker, to determine the sustainable speed. The authors pay attention to the influence of ship operability on ship manoeuvring characteristics in heavy seas, for instance on necessary route and/or speed changes.

An issue which is worth addressing here refers to the database for wave and wind characteristics in a given water region. Traditionally, the data are taken from wave atlases, which are mainly based on observations rather than measurements. Wing and Johnson (2011) have worked out a method to determine wave characteristics from the long term hourly historical wave buoy data, which seem to be more accurate and useful for further embedding into the operability calculation algorithms.

As far as ship operability calculations are concerned, an advanced tool has been delivered by the Department of Marine Technology, Norwegian University of Science and Technology. The basic idea behind ShipX is to make a platform that integrates all kinds of hydrodynamic analysis into an integrated design tool in which the ship operability analysis is available as part of the software.

\section{CONCEPT AND CRITERIA}

The operability limits are usually introduced based on one or a number of the following criteria or standards:

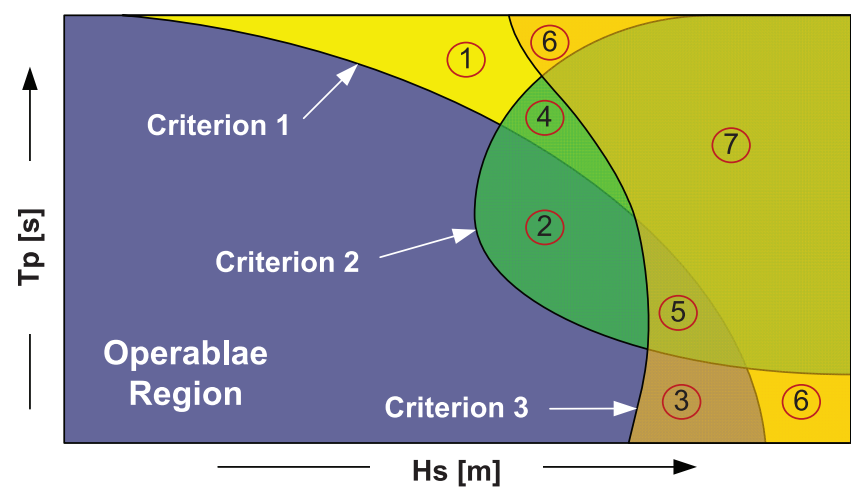

Figure 3. Operability domain and illustration of downtime regions, (Hutchison 1981) 
i. Motion Induced Interruptions (MII), Baitis (1995),

ii. Motion Sickness Incidence (MSI), O'Hanlon and Mc Cauly (1974)

iii. The North Atlantic Treaty Organization Standard Agreement 4154 (NATO STANAG 4154),

iv. U.S. Navy and U.S. Coast Guard Cutter Certification Plan,

v. NORDFORSK (1987)

vi. ISO 2361/3-1985 (in relation to vertical acceleration)

The ship operability limitation criteria usually refer to 9 items:

1. Slam

2. Deck wetness

3. Accelerations (vertical and lateral)

4. Roll

5. Pitch

6. Heave

7. Displacement (particularly, vertical displacement)

8. Local relative motion, which is obtained by subtracting the wave depression from the absolute motion and is positive for the increasing immersion

\section{Propeller emergence}

Sample limiting criteria are given in Table 1. There are also some experts' recommendations for each limiting criterion. For instance, Pipchenko (2011) reports that according to the inquiry of 100 captains and chief mates trained in TCCS ONMA, the limiting criteria may be formulated in the way presented in Table 2. Their illustration is shown in Fig. 4.

The total ship operability analysis should deliver the level for each abovementioned index or limitation criterion and each state of the sea. Then, the multi-criteria decision algorithm is to be used to establish the probability of operability loss in the context of these limitations and indexes regarding the ship mission for possible modes of operation. Additionally, the interactions between the people on board, different ship subsystems, the vessel, the facilities and equipment, the cargo, and external loads should be clearly defined. Depending on the type of connections between different subsystems, the resultant operability indexes may be the maximum values of indexes (for parallel configuration) or the minimum values (for serial configuration). The subsystems, equipment and installations should be divided into two main categories, the

Table 1. General operability limiting criteria for ships (Stevens, 2002, Pipchenko, 2011)

\begin{tabular}{|c|c|c|c|c|c|c|c|}
\hline \multirow{2}{*}{$\begin{array}{c}\text { Ref. } \\
\text { Criterion }\end{array}$} & \multirow{2}{*}{$\begin{array}{l}\text { NATO STANAG } \\
\qquad 154\end{array}$} & \multirow{2}{*}{$\begin{array}{c}\text { U.S. Coast } \\
\text { Guard Cutter } \\
\text { Certification Plan }\end{array}$} & \multirow{2}{*}{$\begin{array}{c}\text { Tasaki et al. } \\
\text { (Japan) }\end{array}$} & \multicolumn{3}{|c|}{ NORDFORSK 1987} & \multirow{2}{*}{$\begin{array}{l}\text { Cruikshank \& } \\
\text { Landsberg } \\
\text { (USA) }\end{array}$} \\
\hline & & & & Merchant ships & $\begin{array}{l}\text { Naval } \\
\text { vessels }\end{array}$ & $\begin{array}{c}\text { Fast small } \\
\text { craft }\end{array}$ & \\
\hline \multirow[b]{2}{*}{$\begin{array}{l}\text { Vertical acceleration at } \\
\text { forward perpendicular }\end{array}$} & \multirow[b]{2}{*}{$0.2 \mathrm{~g}$ RMS } & \multirow[b]{2}{*}{$0.4 \mathrm{~g} \mathrm{SSA}$} & \multirow[b]{2}{*}{$0.80 \mathrm{~g} @ \mathrm{P}=0.001$} & $\begin{array}{c}0.275 \mathrm{~g}(\mathrm{~L} \leq 100 \mathrm{~m}) \\
\text { or } \\
0.05 \mathrm{~g}(\mathrm{~L} \geq 330 \mathrm{~m}) \\
\end{array}$ & $0.275 \mathrm{~g}$ & $0.65 \mathrm{~g}$ & \multirow[b]{2}{*}{$0.25 \mathrm{~g}$} \\
\hline & & & & \multicolumn{3}{|c|}{$\begin{array}{l}0.20 \mathrm{~g} \text { for light manual work } \\
0.15 \mathrm{~g} \text { for heavy manual work } \\
0.10 \mathrm{~g} \text { for intellectual work } \\
0.05 \mathrm{~g} \text { for transit passengers } \\
0.02 \mathrm{~g} \text { for cruise liner }\end{array}$} & \\
\hline $\begin{array}{c}\text { Vertical acceleration at } \\
\text { bridge }\end{array}$ & $0.1 \mathrm{~g}$ RMS & $0.2 \mathrm{~g} \mathrm{SSA}$ & & $0.15 \mathrm{~g}$ & $0.2 \mathrm{~g}$ & $0.275 \mathrm{~g}$ & $0.20 \mathrm{~g}$ \\
\hline \multirow[b]{2}{*}{$\begin{array}{c}\text { Lateral acceleration at } \\
\text { bridge }\end{array}$} & \multirow[b]{2}{*}{$0.10 \mathrm{~g}$ RMS } & \multirow[b]{2}{*}{$0.2 \mathrm{~g} \mathrm{SSA}$} & \multirow[b]{2}{*}{$0.60 \mathrm{~g} @ \mathrm{P}=0.001$} & & $0.1 \mathrm{~g}$ & $0.1 \mathrm{~g}$ & \\
\hline & & & & \multicolumn{3}{|c|}{$\begin{array}{l}0.10 \mathrm{~g} \text { for light manual work } \\
0.07 \mathrm{~g} \text { for heavy manual work } \\
0.05 \mathrm{~g} \text { for intellectual work } \\
0.04 \mathrm{~g} \text { for transit passengers } \\
0.03 \mathrm{~g} \text { for cruiseliner }\end{array}$} & \\
\hline $\begin{array}{l}\text { Motion Sickness } \\
\text { Incidence (MSI) }\end{array}$ & $\begin{array}{l}20 \% \text { of crew in } 4 \\
\text { hours }\end{array}$ & $\begin{array}{l}5 \% \text { in a } 30 \text { minute } \\
\text { exposure }\end{array}$ & & & & & \\
\hline $\begin{array}{l}\text { Motion Induced } \\
\text { Interruption (MII) }\end{array}$ & 1 tip per minute & 2.1 tip per minute & & & & & \\
\hline \multirow[b]{2}{*}{ Roll amplitude } & \multirow[b]{2}{*}{$4.0^{\circ} \mathrm{RMS}$} & \multirow[b]{2}{*}{$8.0^{\circ} \mathrm{SSA}$} & \multirow[b]{2}{*}{$25.0^{\circ} @ \mathrm{P}=0.001$} & $6.0^{\circ}$ & $4.0^{\circ}$ & $4.0^{\circ}$ & \multirow[b]{2}{*}{$15.0^{\circ}$} \\
\hline & & & & \multicolumn{3}{|l|}{$\begin{array}{l}6.0^{\circ} \text { for light manual work } \\
4.0^{\circ} \text { for heavy manual work } \\
3.0^{\circ} \text { for intellectual work } \\
2.5^{\circ} \text { for transit passengers } \\
2.0^{\circ} \text { for cruiseliner }\end{array}$} & \\
\hline Pitch amplitude & $1.5^{\circ} \mathrm{RMS}$ & $3.0^{\circ} \mathrm{SSA}$ & & & & & \\
\hline Slamming (probability) & & & 0.01 & $\begin{array}{c}0.03(\mathrm{~L} \leq 100 \mathrm{~m}) \\
\text { or } \\
0.01(\mathrm{~L}>300 \mathrm{~m})\end{array}$ & 0.03 & 0.03 & 0.06 \\
\hline $\begin{array}{c}\text { Deck wetness } \\
\text { (probability) }\end{array}$ & & & 0.01 & 0.05 & 0.05 & 0.05 & 0.07 \\
\hline $\begin{array}{l}\text { Propeller Emergence } \\
\text { (probability) }\end{array}$ & & & 0.1 & & & & 0.25 \\
\hline
\end{tabular}

* RMS: Root Mean Square, SSA: Significant Single Amplitude (2 times of RMS) 
first of which is related to those subsystems or equipment, whose lack of operability means the lack of operability of the entire ship, while the second group composes the units whose lack of operability does not result in the loss of operability of the whole ship system, although they can provoke inoperability of some other subsystems or equipment.

The total operability assessment should provide the following results:

1. The percentage of time during which the ship and its installations are available for operation, or inversely the time of degradation of ship ability to carry out its mission in calm water conditions.

2. The interaction between the characteristics related to ship manoeuvrability and the operability indexes or limitation criteria, including the sustainable level of the course and speed of navigation for each sea state.

3. Mutual impact of human comfort criteria and the operability, based on general motion limits in relation to biomechanical and physiological effects, which, when exceeded, lead to the degradation of human comfort.

4. Indication which ship subsystem, equipment or installation, and in which order of priority, may fail to perform its function in harsh sea conditions.

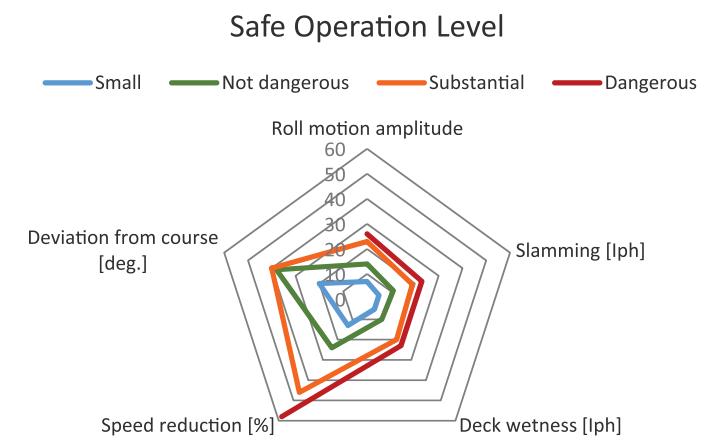

Figure. 4. Safe operation level based on experts' recommendations (Pipchenko, 2011)

For some subsystems or installations, the risk assessment can be considered as a parallel procedure which delivers valuable input data for determining the probability of operability loss. However, the majority of indexes can be calculated directly. Some examples are given below. a. Deck wetness (DW)

The deck wetness, DW, takes place when the relative motion of any part of the hull exceeds the height of the freeboard and may cause, for instance, damage of the equipment or cargo loss. The probability of DW is defined as:

$$
P_{D W}=\exp \left(-\frac{F B_{i}}{2 m_{0}}\right)
$$

where $\mathrm{FB}_{\mathrm{i}}$ denotes the freeboard at the $\mathrm{i}$-th section and $\mathrm{m}_{0}$ is the zero moment of th relative motion spectrum.

\section{b. Vertical Acceleration (VA)}

Like DW, the vertical acceleration, VA, may be dangerous for the crew or people on board, or lead to the damage of equipment, for instance in the case of Offshore Supply Vessels equipped with a crane or gangway at bow. Here, the Root Mean Square (RMS) of the mean acceleration value is calculated and then multiplied by a constant depending on the ship type.

\section{c. Propeller Emergence (PE)}

The propeller emergence, $\mathrm{PE}$, occurs when the relative motion of the ship aft part is faster than the height between the propeller tip and the water line. The probability of PE is defined as follows:

$$
P_{P E}=\exp \left(-\frac{H_{i}}{2 m_{0}}\right)
$$

where $\mathrm{H}_{\mathrm{i}}$ denotes the distance between the water line and the propeller tip.

\section{d. Response Amplitude Operators (RAOs)}

The response amplitude operator, RAO, is often used to denote the ratio between the response amplitude of any analysed variable to the wave amplitude. Its advantage is simple application, while the main disadvantage is the fact that it is a transfer function for linear or linearized systems. In general, the RAOs are the function of wave number $(k)$, ship length $(L)$, ship width $(B)$, Froude number $(F n)$, and block coefficient $(C b)$. A semi-analytical method to calculate the RAOs has been developed and described by Jensen et al. (2004) using the closed-form expression.

Table 2. Limiting criteria recommended by experts (Pipchenko, 2011).

\begin{tabular}{|l|c|c|c|c|c|}
\hline & $\begin{array}{c}\text { Roll motion } \\
\text { amplitude }\end{array}$ & $\begin{array}{c}\text { Slamming } \\
{[\mathbf{I} \text { h] }}\end{array}$ & $\begin{array}{c}\text { Deck wetness } \\
\text { [Iph] }\end{array}$ & $\begin{array}{c}\text { Speed } \\
\text { reduction [\%] }\end{array}$ & $\begin{array}{c}\text { Deviation } \\
\text { from course } \\
\text { [deg.] }\end{array}$ \\
\hline Small (up to) & 7 & 5 & 5 & 13 & 20 \\
\hline Not dangerous (up to) & 14 & 11 & 10 & 24 & 38 \\
\hline Substantial (up to) & 23 & 19 & 20 & 46 & 40 \\
\hline Dangerous (greater than) & 26 & 23 & 23 & 58 & \\
\hline
\end{tabular}

IpH: Intensity per hour 
e. Motion Sickness Incidence (MSI)

The motion sickness incidence, MSI, can be calculated based on the McCauley and O'Hanlon equation that makes it possible to determine the impact of ship motions on the percentage of people that would suffer from sea sickness

$$
M S I=100 \cdot\left[0.5+\operatorname{erf}\left(2.5 \cdot \log _{10}\left(\frac{a_{v}}{g}\right)-\mu_{M S I}\right)\right]
$$

where the error function (erf) is:

$$
\operatorname{erf}(x)=\frac{1}{\sqrt{2 \pi}} \int_{0}^{x} e^{\left(-x^{2} / 2\right)} d x
$$

and $a_{v}$ is the mean value of vertical acceleration at a selected point.

The structure of the total operability assessment algorithm is illustrated in Fig. 5.

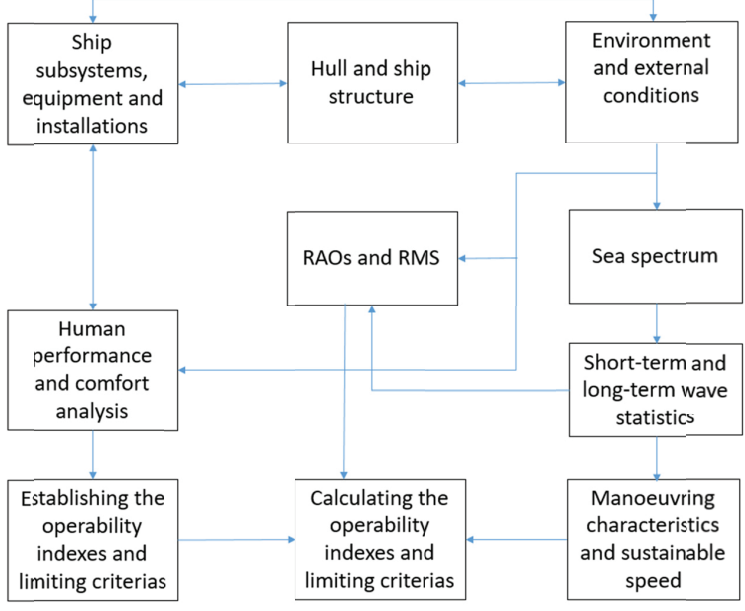

Figure 5. Structure of the total operability assessment algorithm.
It should be emphasised that the majority of the existing operability assessment methods do not include interactions between the ship and ship subsystems. A good example here is the influence of pendulum motion of the cargo suspended by a crane on the ship motion. Table 3 shows essential ship subsystems for which these interactions may have place regarding different operability criteria.

To illustrate the problem of total ship operability, the following example can be considered. The ship selected for the analysis can be a Crane/Workboat Barge or similarly an AHTS, which is equipped with large telescopic boom crane at bow for offshore operations. The crane and the ship are treated as a single rigid body, while the crane barge is not a semisubmersible vessel. It can be supposed that the stabilization of vessel oscillations is controlled only by using passive healing control tanks, and no additional method or stabilizer is taken into account. The rules which are applicable here are those given in LRS Code Lifting Appliances Rules (Jan. 2013), particularly for offshore cranes - Chapter 3, Sections 2 and 3. The vessel is supposed to operate for offshore purposes, mainly loading/unloading processes. The external loads are those imposed by the sea state 3 and the vessel is to be positioned dynamically. In this case there are at least 4 subsystems to be taken into account, which are: the load (a container, for instance) and its pendulum motion, the crane, the propulsion system, and the dynamic positioning system. Additionally, the ship motion and the crew safety and comfort should also be taken into account, see Fig. 6. Consequently, 7 items interact with each other and these interactions should be clearly defined and modelled. The calculation results may include: positions and motions of the load, the crane hook, and the vessel (see Fig. 7), as well as forces and moments acting on each. Then, the abovementioned 4 items of operability results can be determined. Such a study has been done by the authors and the results will be presented in the next article.

\begin{tabular}{|c|c|c|c|c|c|c|c|c|c|c|c|c|}
\hline \multirow[b]{2}{*}{ Ship subsystem } & \multicolumn{12}{|c|}{ Criteria with regard to } \\
\hline & 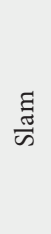 & 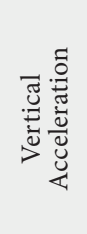 & 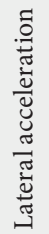 & $\overrightarrow{\bar{\varkappa}}$ & 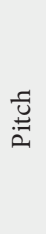 & 芭 & 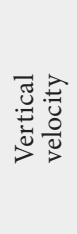 & 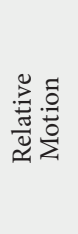 & 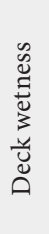 & $\Xi$ & $\stackrel{\vec{n}}{\Sigma}$ & 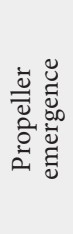 \\
\hline Ship hull & $\mathrm{X}$ & & & & & & & & $\mathrm{X}$ & & & $\mathrm{X}$ \\
\hline $\begin{array}{l}\text { Propulsion system and } \\
\text { machinery }\end{array}$ & & & & & & & & $\mathrm{X}$ & & & & $\mathrm{X}$ \\
\hline Ship equipment & & $\mathrm{X}$ & $\mathrm{X}$ & $\mathrm{X}$ & $\mathrm{X}$ & & & & & & & \\
\hline Cargo & & $\mathrm{X}$ & $\mathrm{X}$ & $\mathrm{X}$ & $\mathrm{X}$ & & & & $\mathrm{X}$ & & & \\
\hline Personnel effectiveness & & $\mathrm{X}$ & $\mathrm{X}$ & $\mathrm{X}$ & $\mathrm{X}$ & & & & $\mathrm{X}$ & $\mathrm{X}$ & $\mathrm{X}$ & \\
\hline Passenger comfort & & $\mathrm{X}$ & $\mathrm{X}$ & $\mathrm{X}$ & $\mathrm{X}$ & $\mathrm{X}$ & & & & $\mathrm{X}$ & $\mathrm{X}$ & \\
\hline Helicopter & & & & $\mathrm{X}$ & $\mathrm{X}$ & $\mathrm{X}$ & $\mathrm{X}$ & & & & & \\
\hline Sonar & & & & & & & & $\mathrm{X}$ & & & & \\
\hline $\begin{array}{l}\text { Lifting and loading/ } \\
\text { unloading operations }\end{array}$ & $\mathrm{X}$ & & $\mathrm{X}$ & $\mathrm{X}$ & $\mathrm{X}$ & $\mathrm{X}$ & $\mathrm{X}$ & & $\mathrm{X}$ & & & \\
\hline $\begin{array}{l}\text { Anchoring and Mooring } \\
\text { system }\end{array}$ & $\mathrm{X}$ & $\mathrm{X}$ & $\mathrm{X}$ & & & & & $\mathrm{X}$ & $\mathrm{X}$ & & & \\
\hline Dynamic positioning & & $\mathrm{X}$ & $\mathrm{X}$ & $\mathrm{X}$ & $\mathrm{X}$ & $\mathrm{X}$ & $\mathrm{X}$ & $\mathrm{X}$ & & & & $\mathrm{X}$ \\
\hline
\end{tabular}

Table 3 Interactions between the ship and ship subsystems regarding different criteria (mainly based on the ShipX User Guide). 


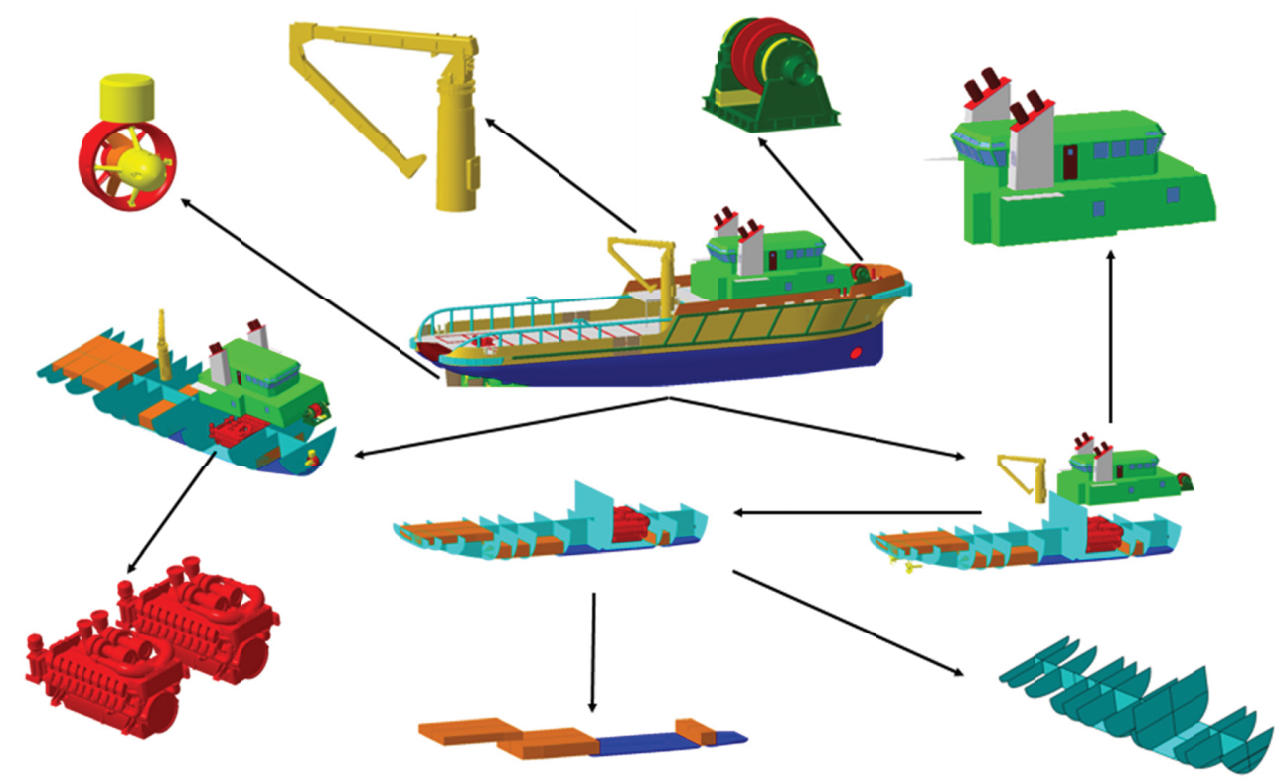

Figure 6. Subsystems and installations considered for operability assessment.

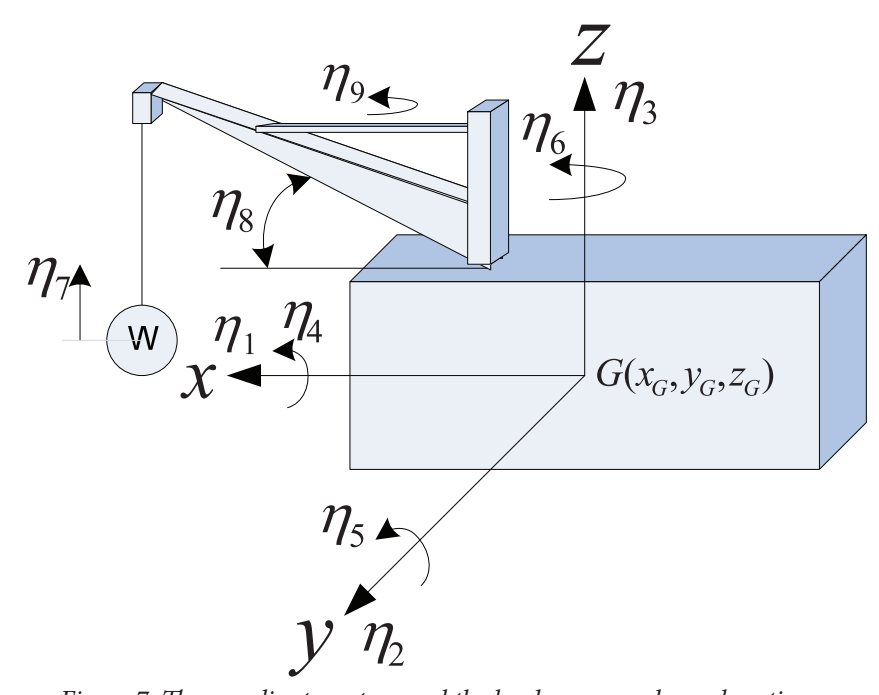

Figure 7. The coordinate system and the load, crane and vessel motions.

\section{REFERENCES}

1. Baitis, A. E., Holcombe, F. D., Conwell, S. L., Crossland, P., Colwell, J., and Pattison, J. H.: Motion Induced Interruptions (MII) and Motion Induced Fatigue (MIF) Experiments at the Naval Biodynamics Laboratory, Technical Report CRDKNSWC-HD-1423-01, Bethesda, MD: Naval Surface Warfare Center, Carderock Division, 1995.

2. Burdziakowski P., Janowski A., Kholodkov A., Matysik K., Matysik M., Przyborski M., Szulwic J., Tysiąc P., Wojtowicz A.: Maritime Laser Scanning as The Source for Spatial Data. Polish Maritime Research, Vol. 22, No. 4(88) (2015), pp.9-14., 2015.
3. Dallinga R., Daalen E. V., Grin R., Willemstein T.: Scenario Simulations in Design for Service. Proc. of 9th Symposium of Practical Design of Ships and Other Floating Structures (PRADS2004), Volume 2, pp 604-611, 2004.

4. Faltinsen O. M., Sea Loads on Ships and Offshore Structures. Cambridge University Press, ISBN 0521458706, 1998.

5. Fathi D., Hoff J. R., MARINTEK A/S, ShipX User Manual, 2004.

6. Grin R. and Van De Voorde E.: Weather-Related Economics of Natural Gas Transport for Two Propulsion Plant Configurations. RINA 2004 Conference: Design and Operation of Gas Carriers. CD-ROM, 2004.

7. Hutchison B. L.: Risk and Operability Analysis in the Marine Environment. SNAME Transactions, Vol. 89, pp. 127-154, 1981.

8. Janowski A., Nowak A., Przyborski M., Szulwic J.: Mobile indicators in GIS and GPS positioning accuracy in cities. 2nd International Conference on Rough Sets and Emerging Intelligent Systems Paradigms (RSEISP) held as part of Joint Rough Set Symposium (JRS), 2014, Springer International Publishing, ISBN:978-3-319-08729-0; 978-3-319-08728-3, DOI: 10.1007/978-3-319-08729-0_31, 2014.

9. Jensen J., Mansour A. E., Olsen A. S.: Estimation of Ship Motions Using Closed-form Expressions. 'Ocean Engineering', 2004, 31, pp. 61-85, 2004.

10. Wilde J. J. de, Van Dijk A. W., Van Den Berg J., Dekker J., et al.: Direct Time Domain Downtime Assessment for Long Operations Using Computer Cluster, The Nineteenth 
International Offshore and Polar Engineering Conference, International Society of Offshore and Polar Engineers, 2009.

11. Feikens H., Verwey R., Serraris J. J., Huijsmans R.: “Wet handshake": Workability Study of an Offshore Thruster Exchange Operation. ASME 30th International Conference on Ocean, Offshore and Arctic Engineering, pp 609-616, American Society of Mechanical Engineers, 2011.

12. Mudronja L.: Numerical Evaluation of Operability Envelope for Ultra Large Container Ship in Extreme Seas and Influence of Maneuvering on Wave Loads, Presented in the 21st Symposium on Theory and Practice of Shipbuilding - SORTA 2014 (2 to 4 October 2014 in Baška, Island of Krk, Croatia), 2014.

13. Mudronja L., Katalinić M., Bošnjak R., Vidan P.: Operability Guidelines for Product Tanker In Heavy Weather in The Adriatic Sea. Annual of Navigation 21 /2014, DOI: 10.1515/ aon-2015-0008, 2014.

14. Naito S., Minoura M., Hamanaka S., Yamamoto T.: LongTerm Prediction Method Based on Ship Operation Criteria. International Shipbuilding Progress, 53 (3):229-252, 2006.

15. Nordforsk, Assessment of Ship Performance in a Seaway: The Nordic Co-operative Project: "Seakeeping Performance of Ships”, ISBN 8798263714, 9788798263715, 1987.

16. Ochi M. K.: Principles of Extreme Value Statistics and Their Application. In: Extreme Loads Response Symposium, SNAME, Arlington, VA, pp 15-30, 1981.

17. Pipchenko A. D., Zhukov D. S.: Ship Control Optimization in Heavy Weather Conditions. International Association of Maritime Universities AGA11, 2011.

18. Rusu L., Bernardino M.: Estimation of The Operability Index of A Containership Operating In The Black Sea. The Annuals of University "Dunărea De Jos" of Galati Fascicle VIII, 2009 (XV), ISSN 1221-4590 TRIBOLOGY, 2009.

19. Sabik A., Kreja I.: Large Thermo-elastic Displacement and Stability FEM Analysis of Multilayered Plates and Shells. THIN-WALLED STRUCTURES. -Vol. 71, (2013), pp.119$133,2013$.

20. Stevens S. C., Parsons M. G.: Effects of Motion at Sea on Crew Performance: A Survey. Marine Technology, Vol. 39, No. 1, pp. 29-47, January 2002.

21. Szłapczyński R.: Evolutionary Planning of Safe Ship Tracks in Restricted Visibility. Journal of Navigation, Vol. 68, No. 01 (2015), pp 39-51, 2015.

22. Szłapczyński R., Szlapczynska J.: A Target Information
Display for Visualising Collision Avoidance Manoeuvres in Various Visibility Conditions. Journal of Navigation, Vol. 68, No. 06 (2015), pp.1041-1055, 2015.

23. Tezdogan T., Incecik A.: Operability assessment of high speed passenger ships based on human comfort criteria. Ocean Engineering, Volume 89, 1 October 2014, Pages 32-52, ISSN 0029-8018, DOI: 10.1016/j. oceaneng.2014.07.009, 2014.

24. Vidal, H.L., Gaspar, H.M., Weihmann, L. et al.: Mar Syst Ocean Technol (2015) 10: 47. doi:10.1007/s40868-015-00018, 2015.

25. Wing D. A., Johnson M. C.: Ship Operability Predicted from Long Term Directional Wave Records, Transactions RINA, Vol 153, Part A2, International Journal Maritime Engineering, DOI No: 10.3940/rina.ijme.2011.a2.wf5, AprJun 2011.

26. Zeraatgar, H.; Rostami, A. B.: An Investigation on Ship Operability Versus Equipment Operability in Irregular Waves, Brodogradnja, Brodarski Institut doo, pp 30-34, 2012.

\section{CONTACT WITH THE AUTHOR}

\author{
M. Hossein Ghaemi \\ Gdańsk University of Technology \\ Faculty of Ocean Engineering and Ship Technology \\ 11/12 Narutowicza St. \\ 80 - 233 Gdańsk \\ Poland
}

